This is the authors' version of an article published as: Ghazali, G. and Bennett, D. 2017. Employability for music graduates: Malaysian educational reform and the focus on generic skills. International Journal of Music Education. 35 (4): pp. 588-600.

DOI: $10.1177 / 0255761416689844$

\title{
Employability for music graduates: Malaysian educational reform and the focus on generic skills
}

\begin{abstract}
In Malaysia, the demand for employable higher education graduates has resulted in a national strategy that outlines desirable graduate attributes including 'hard', discipline-specific skills and 'soft', generic skills. As a result, music programs are under pressure to become more relevant to the conditions and characteristics of the industry. This article presents an overview of the whole-of-education trends in Malaysia and then reports empirical data from eight Malaysian music professionals, all higher education music graduates, who described their presage, transitional and career experiences. Participants emphasised that hard and soft skills are equally important dimensions of graduate employability, which supports the heightened national focus on generic skills. However, participants' focus was not on the skills per se; rather, they stressed the need for students to apply and reflect upon their development of skills during their studies. The article aligns this thinking with the Malaysian strategy and a commonly used employability framework to illustrate the soft skills that might be required of music graduates.
\end{abstract}

Keywords: graduate careers, arts, soft skills, generic skills, curriculum, transition

\section{Introduction}

Higher education has an ethical imperative to ensure that graduates are prepared, resourceful and industry aware; however, Bartleet et al. (2012) and Barkl (2008) amongst others have emphasised concerns about the ability of music graduates to negotiate their career transition. Building on work in the United Kingdom (UK) (Frenette \& Tepper, 2016), United States (US) 
(Pike, 2014) and Australia (Tolmie, 2014), this article reports from a study that focused on employability in the Malaysian context, mapping a decade of reform and then working with established practitioners to understand the characteristics of music work and the extent to which higher music education aligned with their employability needs. Given the definitional shift in employability from getting a traditional job to developing the individual, the study defined effective employability development as “fostering students' professional identities along cognitive dimensions with respect to their dispositions and capacities to engage as professionals concerns development of the whole individual” (Bennett, 2016, p. 392).

The focus of this article is generic or "soft" skills, which are the subject of scrutiny across Malaysian education; to align with the Malaysian context we adopt the terms soft and hard (discipline specific) skills throughout the article. We begin somewhat unusually with a description of the study approach, which was both theoretical and empirical. We then present an extended overview of the Malaysian context, addressing a time of considerable and nationwide change in education. This is followed with discussion of the soft and hard skills that form the criteria for assessing higher education employability. We then report and discuss the empirical data as they relate to participants' experiences prior to post-secondary studies, during their transition from study to work, and as graduates. We consider these findings in relation to the metaphorical employability model developed by Dacre Pool and Sewell (2007), and from this we suggest implications and avenues for future research.

\section{Approach}

\section{Theoretical phase}

The theoretical phase of this study involved an appraisal of the Malaysian context, specifically the reviews undertaken by the Ministry of Higher Education (MOHE) and the Ministry of Education (MOE), and the alignment of this work with scholarly understanding of 
employability in a higher education context. To understand how the two were brought together, we first note common definitions of employability. These include "the capability to move selfsufficiently within the labour market to realise potential through sustainable employment" (Hillage \& Pollard, 1998, p. 2); “a set of achievements - skills, understandings and personal attributes - that makes graduates more likely to gain employment and be successful in their chosen occupations" (Yorke, 2004, p. 8); and "skills, knowledge, understanding and personal attributes that make a person more likely to choose and secure occupations in which they can be satisfied and successful" (Dacre Pool \& Sewell, 2007, p. 280).

The employability review conducted by MOHE adopted Mantz and Yorke's (2006, p. 3) definition of employability:

a set of achievements - skills, understandings and personal attributes - that make graduates more likely to gain employment and be successful in their chosen occupations, which benefits themselves, the workforce, the community and the economy.

Also important in the Malaysian context were Dacre Pool and Sewell's (2007) five elements of employability success known as "Career EDGE": Career development learning; Experience (work and life); Degree subject knowledge, understanding and skills; Generic skills; and Emotional intelligence. The seven soft skill elements that make up the resulting Employability Attributes Framework (EAF) (2012) are most closely aligned with this model, with specific reference to the element known as generic skills: 15 skills ranging from teamwork to responsibility for making decisions.

The whole-of-education (school and university) reviews described in our Findings section prompted MOHE to identify and publish the desirable generic student attributes for all Malaysian higher education graduates (MOHE, 2012). This issue had interested the Ministry for several years: in an earlier MOHE publication (2006), soft skills were defined as "cognitive elements related to non-academic abilities, such as positive values, leadership, teamwork, 
communication and lifelong learning” (MOHE, 2006, p. 5). Thirty-four soft skills were identified at that time, and these were divided into two categories: 18 "must have" and 16 "good to have" skills. According to Salih (2008), the "must have" soft skills were skills that students must acquire in order to be deemed competent. They were transferable, essential, and applicable across all disciplines and fields of knowledge. The "good to have" soft skills were positioned as desirable rather than essential. The 2012 EAF refined this list to focus on seven core soft skills shown at Table 1 .

The other component considered in this study was the instrument known as the Malaysian Soft Skills Scale (My3S), which was designed by the Ministry to measure university students' perceptions of their soft skills attainment. The instrument was administered to all university students for the first time in 2010. Although it predates the EAF, the 180-item instrument probes the seven core soft skills shown at Table 1. Data are not publicly available; however, the instrument has been endorsed by the Ministry to measure the effectiveness of soft skills development across Malaysian higher education.

Table 1: Malaysian core soft skills elements in the 2012 Employability Attributes Framework

\begin{tabular}{lc}
\hline Soft skill & My3S items in which the skill is assessed (count) \\
\hline Communication & 30 \\
Critical thinking \& problem solving & 30 \\
Teamwork & 30 \\
Moral and professional ethics & 30 \\
Leadership & 20 \\
Life-long learning and Information management & 20 \\
Entrepreneurship & 20 \\
\hline
\end{tabular}

Source: Syed Aris, (2012). Note: the Ministry document is not publicly available 


\section{Empirical phase}

The empirical phase of the study involved eight established music practitioners based in Malaysia. Purposive convenience sampling was used to identify four initial respondents. To maximise diversity within the limited circle of music professionals in Malaysia, initial sample selection emphasised range of experience, ability to speak from a number of perspectives and experiences (a representative voice), diverse roles in industry organisations, and experience of working with and/or employing music graduates. Gender balance was also sought.

The four initial practitioners were based or located within and around the city of Kuala Lumpur. Using a chain referral approach, these practitioners identified potential respondents not known to the interviewer. This article reports from the eight in-depth interviews conducted with the final sample. Participants were assured of their anonymity and in the article they are given pseudonyms. Four participants had studied music at international universities (Joe, DM, Zack and Mus); the remaining four participants (Ozer, Delli, Alyn and Lina) were alumni of Universiti Teknologi Mara (UiTM). Demographic profiles are described at Table 2.

Table 2: Demographic profile of participants

\begin{tabular}{lllll}
\hline Name & Gender & Age & $\begin{array}{l}\text { Years in } \\
\text { music }\end{array}$ & Music work \\
\hline Joe & M & 74 & 46 & Conductor, arranger, part-time lecturer, trumpeter \\
DM & M & 52 & 24 & Music director, conductor, arranger, pianist \\
Mus & M & 54 & 15 & Conductor, violinist, part-time lecturer, instrumental teacher \\
Zack & M & 53 & 27 & Music producer, director, arranger, guitarist, record producer, \\
& & & & part-time lecturer, private instrumental teacher \\
Ozer & M & 40 & 18 & Music producer, director, arranger, keyboard player, part-time \\
& & & & lecturer \\
Delli & F & 38 & 14 & Choral trainer, conductor, vocalist, part-time lecturer \\
Alyn & F & 47 & 6 & Band director, pianist \\
Lina & F & 26 & 2 & Choral and voice trainer, vocalist \\
\hline
\end{tabular}




\section{Procedure}

Once ethical approvals were in place, eight one-to-one, semi-structured interviews were carried out in person at venues and times nominated by participants. The interview instrument was shaped by the theoretical component of the study and was trialled before use. The interviews probed respondents' thinking around three themes and from three perspectives: as student and emerging professional; as established professional; and as employer, manager and mentor:

- Higher education and the transition to professional career;

- Characteristics of work; and

- Recruitment of, and work with aspiring and emerging professionals.

Each interview took approximately two hours and was recorded using a digital voice recorder. Interviews were translated and transcribed for the purpose of analysis. Responses were first analysed and coded according to themes and categories based on the broad sections of the interview protocol. Each theme and category was then subject to a finer-grained analysis during which responses were aligned with the Malaysian Ministry of Higher Education's soft skills. These were mapped concurrently with Dacre Pool and Sewell's employability elements.

\section{Findings}

This study involved an extensive review of music education in Malaysia followed by data collection in the form of interviews with musicians. We report each of these phases in turn, beginning with an overview of the Malaysian context and the skills that form the criteria for assessing higher education employability, and then reporting the empirical findings. 


\section{Understanding the context of change: From grades to generic skills}

Music education in Malaysia The theoretical component of this study involved a review of the widespread changes impacting Malaysian music education from primary school to tertiary level. In line with many other countries, the Malaysian education system provides access to music education in primary and secondary schools; however, the intensity of music learning experiences varies in both classroom and co-curricular music opportunities. The systemic deemphasis of school music was evidenced in a 2011 Ministry of Education decision to halve weekly primary school music classes from one hour to just 30 minutes. Although 30-minutes of music remains mandatory in primary schools, not all schools have the means or facilities to accommodate a music program. Within those schools where music is delivered, music is often at risk of being replaced with so-called "core" subjects such as math, science and languages. This most often occurs on a temporary basis towards the end of the school year, at which time exams draw near and extra classes in core subjects are deemed necessary (Ghazali, 2006).

Access to music education is most divergent at the secondary school level, where music is in decline: in 2014 it was offered at only $11 \%$ of public schools (Curriculum Development Centre, 2014). In contrast, more privileged regular and government-funded residential schools, as well as the Malaysian arts schools, offer a diverse music curriculum with ensemble opportunities such as choirs, school bands, and wind or string orchestras. Opportunities to showcase musical achievements come in the form of annual state, regional and national competitions, often with support and sponsorship from parent-teacher associations and other private sources.

In parallel with school-based music provision is the formal and informal music learning that occurs at private music centres situated in state capitals and cities. These centres provide structured and focused performance training, and most private music students in Malaysia undertake external performance examinations such as those run by the Associated Board of the Royal Schools of Music, Guildhall, Trinity and Yamaha. Graded music certificates demonstrate 
extracurricular achievement and are often regarded as a safety net for those who do not excel in their academic studies. This indicates a belief that a career in music (most often in teaching) is a viable career option for Malaysian students (Ghazali, 2006). The result of these varied experiences prior to post-secondary studies is a population of Malaysian school leavers with vastly different musical exposure, experiences and competencies, who apply to common higher education music programs at the level of diplomas and degrees.

Seven of the 20 public universities in Malaysia offer music programs (MOHE, 2010). UiTM was the first of these, in 1984. In 2009, the Ministry of Higher Education convened a committee of university academics to discuss the future of music education in Malaysian public higher education institutions. The committee considered trends and changes within the industry and the implications of these for higher education. The report (MOHE, 2010) concluded that programs offered in the public universities were overly focused on professional skills in music education, performance, composition, ethnomusicology, music technology and/or jazz. The development of associated soft or generic skills was not considered at that time.

The school education blueprint and higher education plan Shortly after the $2010 \mathrm{MOHE}$ study, in 2011 the Malaysian Ministry of Education (MOE) sought to address the needs of preschool to post-secondary education by implementing the Malaysia Education Blueprint 20132025. The Blueprint stated that the "objective of any education system is to ensure that its students are being equipped with the knowledge and skills required for success in life" (MOE, 2013, p. E-4). Using the Blueprint, the Ministry proposed to transform the country's education system over the following twelve years via "11 strategic and operational shifts" (MOE, 2013, p. E-1). These included inculcation of higher order thinking skills among secondary school students to produce a younger generation better able to function in society as a competent workforce. 
Prompted by the school education Blueprint process alongside a diverse $21^{\text {st }}$ century labour market and concerns about employability among Malaysian youth, the MOE reviewed school curriculum. One of the concerns addressed by the Ministry was that the Malaysian education system was too exam oriented. Indeed, public obsession about academic achievement and excellence in the various national exams, particularly the Malaysian School Certificate examination held at the end of Form Five (the final year of high school), had reached the point at which schooling seemed to overlook the development of personal skills and attributes (soft skills) in favour of academic grades (MOE, 2013).

Scrutiny of the attributes of higher education entrants, a product of the exam-focussed school system, led to further discussions and research around the importance of developing soft skills among school students (Abas \& Koi, 2014; Mohamad, 2014) and among higher education students (MOHE, 2010; Pillai, Khan, Ibrahim \& Raphael, 2012). At this time, the issue of soft skills came into public view with discussions on television talk shows, forums, and morning television segments in which commentators stressed the need for Malaysian children and youth to develop the soft skills needed for future job markets.

Almost concurrent with the Malaysia Education Blueprint 2013-2025 and the last in this suite of reviews was a Blueprint co-designed by academics and industry experts whose focus was higher education graduate employability and the development of transferable skills. This second Blueprint, the Graduate Employability Blueprint (GEB) 2012-2017, was the product of roundtable discussions, dialogues and workshops focussed on what was required for graduates to secure and sustain employment. However, whilst the GEB included the issue of employability in the arts and social sciences, it did not specifically address the challenging and dynamic fields of music and the performing arts, whose graduates face distinct and as yet unmet employability challenges (MOHE, 2010). 
We note that at the time of writing (2016), UiTM was piloting with incoming students a MOHE assessment tool known as the Integrated Cumulative Grade Point Average (iCGPA). The tool was designed to assess both hard and soft skills, including psychomotor and affective skills, within the Malaysian Qualifications Framework (MQF). The eight MQF domains are a refinement of the seven My3S soft skills; under the new program, student achievement in each of the domains will be summarised for each semester in the form of a chart. We have created an example of this at Figure 1. The charts are designed to give students a visual of their progress and future employers a better picture of the graduate seeking employment.

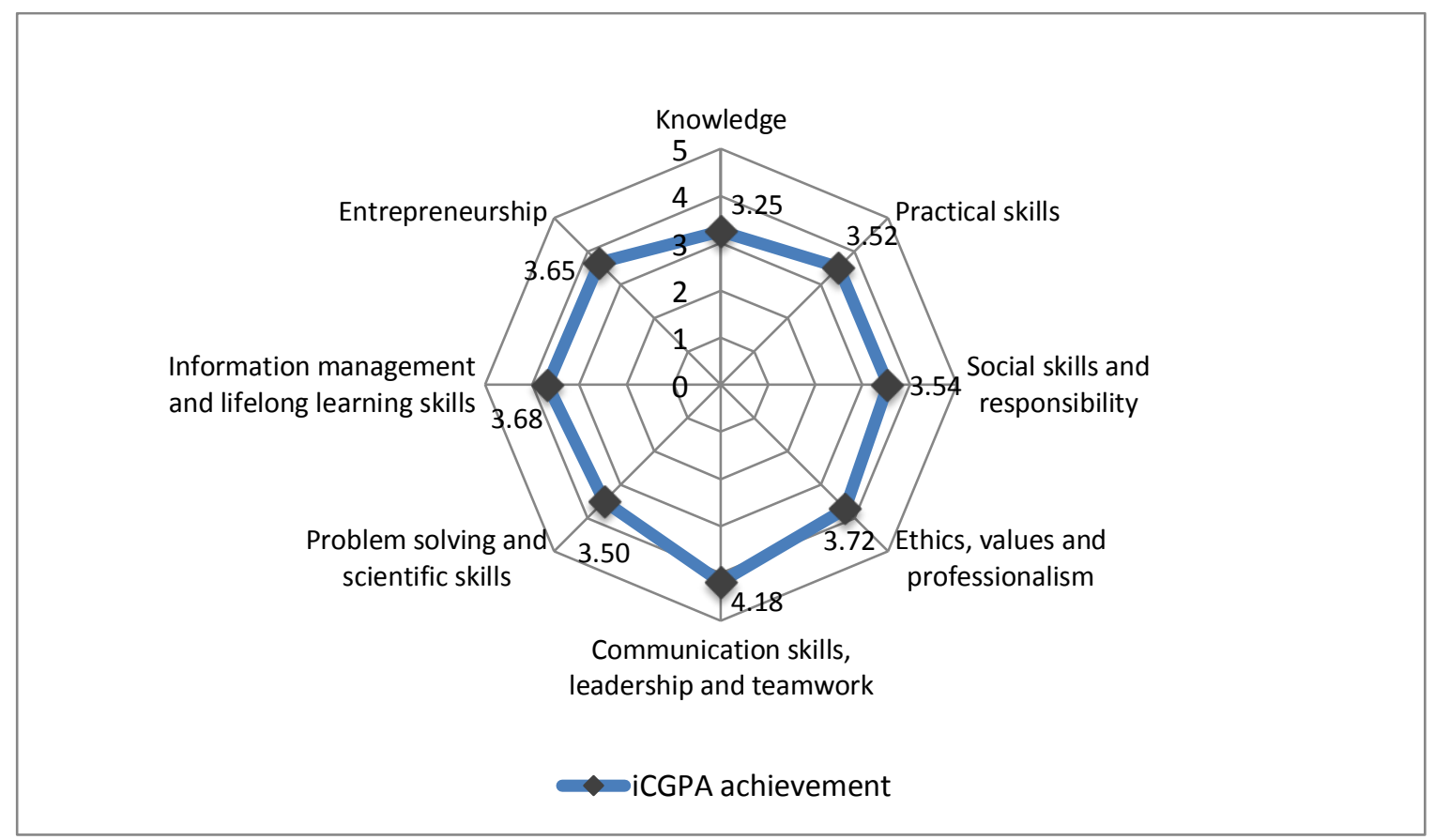

Figure 1: Example of an individual integrated cumulative grade point average (iCGPA)

On the whole, the focus of this widespread change aligns with current thinking about employability as a career-long concern for which workers need "employability assets" (Hillage \& Pollard, 1998) such as disciplinary knowledge and skills, workplace and career awareness and experience, efficacy beliefs, and metacognition. To maintain their employability, workers need to continually update these assets in line with opportunities and interests. In the next 
section we describe how eight professionals working in Malaysia developed and experienced these employability assets.

\section{Generic skills in practice}

This section concerns the eight established music practitioners, who presented diverse and representative views of music practice in Malaysia. All eight participants reported active industry participation before graduating from higher education, prompted by their own efforts and/or the encouragement of teachers from the second year of study. In this study the male participants, regardless of local or overseas education, reported that they had been encouraged to perform outside the university. Joe, DM, Mus and Zack, who had studied overseas, reported performing with their professors outside of the university, while Joe had been invited to perform with faculty members in their groups on a regular basis. Participants who had studied in large musical centres such as New York spoke of myriad performing opportunities outside of university - many more than were available to their locally trained peers. Joe and Zack's words are included below.

- Outside the school I joined a lot of orchestras ... big orchestras, small orchestras. Even faculty members have their own group where they performed outside. I was the only student in the faculty group. (Joe)

- I was with a jazz teacher that I wanted to learn from and he got me to play a lot, performing in school [university] first ... so immediately after school I got all my gigs lined up. (Zack)

Similarly, the four locally trained participants (both male and female) reported active participation in industry concerts, gigs and shows in hotels and clubs. These opportunities were a result of being introduced to professional musicians and becoming part of music networks from which came invitations as back-up performers. The Malaysian music industry is relatively small and it is geographically focussed in metropolitan areas. Musicians and other artists, producers, directors, composers, entertainers and related workers form part of interlocking 
professional networks. Because of the small industry, many capable higher education music students regularly perform in professional stage shows or provide services for concerts and gigs outside the university, regardless of genre. These students can become part of valuable music networks early in their performance training, as was the case for Lina and Ozer.
- I was doing part time [work] even before I graduated ... It all started from there. (Lina)
- When I was at third year at UiTM, I jammed [with] a lot [of] with people outside. Maybe I was lucky when one keyboardist was not available ... one musician asked me if I could play. So they auditioned me immediately and I got it. It was for a rock concert. From then on I started working. (Ozer)

\section{The first year of graduate life}

Asked about their first year after graduation, all eight participants reported that their pregraduation work had continued and none of the participants had found it difficult to earn a living through music. However, performance was only one aspect of their practice. Probing for more in-depth information about the nature of this work, teaching emerged as an important and valued component of participants' portfolios. Mus, for example, studied overseas and had taught music privately whilst a student. He had also performed in chamber and orchestral groups in Germany and the Netherlands. Upon returning to Malaysia, acquaintances helped initiate performances in order to promote him to the Malaysian public. As seen in his comment below, his teaching experience enabled him to amass sufficient music work to make a living.

- The first year I didn't have a full time job, I just had part-time jobs. [My work now is] not a full time job, but if you accumulate everything it's quite a lot. You have part-time job at the university, you have private students, and you have gigs, you have recording, and then besides that to sell yourself you have to do concerts. (Mus)

Similarly, Alyn, who studied at UiTM, reported that on her final day at university she was informed of a teaching vacancy at the State Education Department. Her preparedness for work enabled her to secure the position, but she later transferred her skills into a new setting. 
- Right on the very last day at UiTM, my friend told me about a vacancy ... After one year as a music teacher I worked as a musician [performer], then I got into the police force. They wanted a women's police band and were looking for a woman to be in charge. (Alyn)

Some participants noted having a competitive edge over musicians graduating from private universities because of their broad exposure to different genres of music. This, they felt, was the result of higher music education that focused almost entirely on practical experiences.

\section{Professional practice}

When asked how tertiary education had helped them in the development of both hard and soft skills, respondents stressed the importance of having good technical skills on their instruments (hard skills), but also the soft skills and personal attributes needed to both secure work and sustain their careers. The most important soft skill named by participants was discipline, which participants felt to be applicable to many aspects of musical life.

- Discipline ... music professionals ... need to discipline themselves. That's for the habit of practicing, of playing ... for both music and non-music. If you're on time then you will know how much time you can save. In music professionals it's very, very important. (Zack)

- Discipline ... very important! Because of [poor] discipline you're a bad player. Because of [poor] discipline you are a bad manager. Because of [poor] discipline you cannot get a job. It's all back to discipline. (Mus)

- Discipline is very important. Discipline is not only coming in early, but what you do when you have arrived. (DM)

- Discipline means everything ... in your practice, you have to be prepared. Don't come for rehearsals and make it difficult for others because you didn't practice! (Delli)

For Alyn, the police force band director, discipline also involved confidence and a good overall image, which were crucial for both police musicians and the police force in general. Underpinning these attributes and perhaps highlighting Alyn's ability to transfer her skills and 
knowledge to new settings and challenges were the soft skills of confidence, courage, adaptability and interpersonal skills.

- While musical skills are important, confidence, courage to face challenges, able to adapt to situations and having good PR [public relations] skills are important. (Alyn)

Not surprisingly, participants named musicality as an essential attribute. However, when asked to expand on this they did not talk about technical skills. Rather, they stressed the importance of commitment and passion (or soul) for music, without which they did not believe a career in music was possible.

- When you have the right soul all the technical abilities will fall into place. If you don't have it in here [showing his heart] ... please, quit! Why waste your time, why waste your money? You will get really frustrated 'cos you're not going to be called ... 'cos you don't have it in you. (Zack)

With reference to negotiating careers within the competitive world of music, participants emphasised the need for good work ethics, problem-solving skills and critical thinking skills.

- You have to be professional [in] how you think, how you behave, how you carry yourself ... In dealing with people who are not professional, you have to be professional yourself. You have to educate them ... you have to advise them ... even up to the Minister level! They will ask for your expertise ... at times you can oblige them, at times you cannot ... it depends on the situation. (DM)

- You have to be honest and sincere, not just working for the money. I have seen people who are calculative and not sincere in their efforts, just because they are not paid well. (Delli)

Of interest, participant feedback regarding possible gaps in higher music education was focussed on standards at entry rather than at the point of graduation. This comes from the fact that many students in Malaysia enter higher education with little formal music training, which necessitates accelerated learning in order to achieve the required standards. Despite the need to acquire both technical and theoretical skills and knowledge at an accelerated rate, and in line with Malaysian educational policy, participants felt strongly that the development of soft skills was equally if not more important. 


\section{Discussion}

Becoming a musician involves many years of education and many hours of practice (Ericsson, Krampe \& Tesch-Römer, 1993). This hard work and effort is an investment in future success in music; nonetheless, careers in music are challenging and highly competitive in nature, and neither talent nor experience is sufficient to guarantee graduate employability. Scholars agree that establishing and maintaining a career in any discipline requires both hard skills and soft skills (Dacre Pool \& Sewell, 2007; Syed Aris, 2012); but are skills alone sufficient to meet the needs of emerging graduates?

The Malaysian music professionals who contributed to this study advocated strongly that soft skills should be a core focus of higher music education. In general, the transition to work was relatively smooth for these participants and they were able to earn a living. For Joe, DM, Mus and Zack, whose higher education and industry experiences occurred outside of Malaysia, track record (reputational capital) and the status of overseas study (institutional capital) eased the transition into the Malaysian music industry. For the others, experience in the local industry enabled existing work to be continued and extended.

Participants emphasised that soft skills should be developed and applied in industry as early as possible during university studies. They all noted the benefits of regular opportunities to apply their university learning to performance activities outside of university. These, they claimed, were critical in boosting their employability. The point they were making is that soft and hard skills not applied or subjected to critical reflection are simply skills. Following Kolb (1984, p. 41), skills became knowledge "through the transformation of experience".

Participants described such transformations as a progression of reflection-inspired transitions from theory to practice and back to theory as they learned through experience to reflect on their experiences, to identify skills and attributes needing further development, and to explore new aspects of the industry. 
The importance of applied or experiential learning is not new; however, the general importance of work during study is only now beginning to emerge. Bennett, Richardson and Mackinnon's Australian graduate employability study (2016), for example, found that the single biggest indicator of graduate employment success was work undertaken during the final year of university study, even when that work was unrelated to the student's discipline area. The researchers attributed this to heightened self-efficacy, which Bandura (1986) defines as belief in one's ability to accomplish a task. Self-efficacy is the result of mastery and vicarious experiences, social persuasion and psychological state. Six of the eight participants raised the issue of self-efficacy, explaining that skills and knowledge in combination with their practical experiences as professional musicians had given them more confidence to seek work during the transition from study to work, more confidence to apply their skills in new settings, and more confidence to be entrepreneurial in their creation of new opportunities. In short, active involvement in the industry even before graduating helped to secure graduate work because reflection-inspired practice, professional networks and professional self-efficacy had already been established.

Table 3 illustrates common themes that emerged from mapping the participant narratives against the Malaysian Employability Attributes Framework and the generic skills set in Dacre Pool and Sewell's framework, but with the added emphasis of self-efficacy gained through experience. Although hard skills are not the focus of this article, we note that these were positioned in a similar way. For example, music harmony and music arrangement skills were identified as important aspects of graduate marketability; yet participants' ability to leverage these skills came from the fact that at graduation they had already applied them in industry. Participants acknowledged that it is not possible to learn everything one needs to know within the time it takes to complete a degree. This relates to the employability dimension of life-long 
learning, which requires graduates to adopt critical thinking and problem solving skills. For this reason, at Table 3 these two Dacre Pool and Sewell categories have been combined.

Table 3: Synthesis of recommended generic skills in music

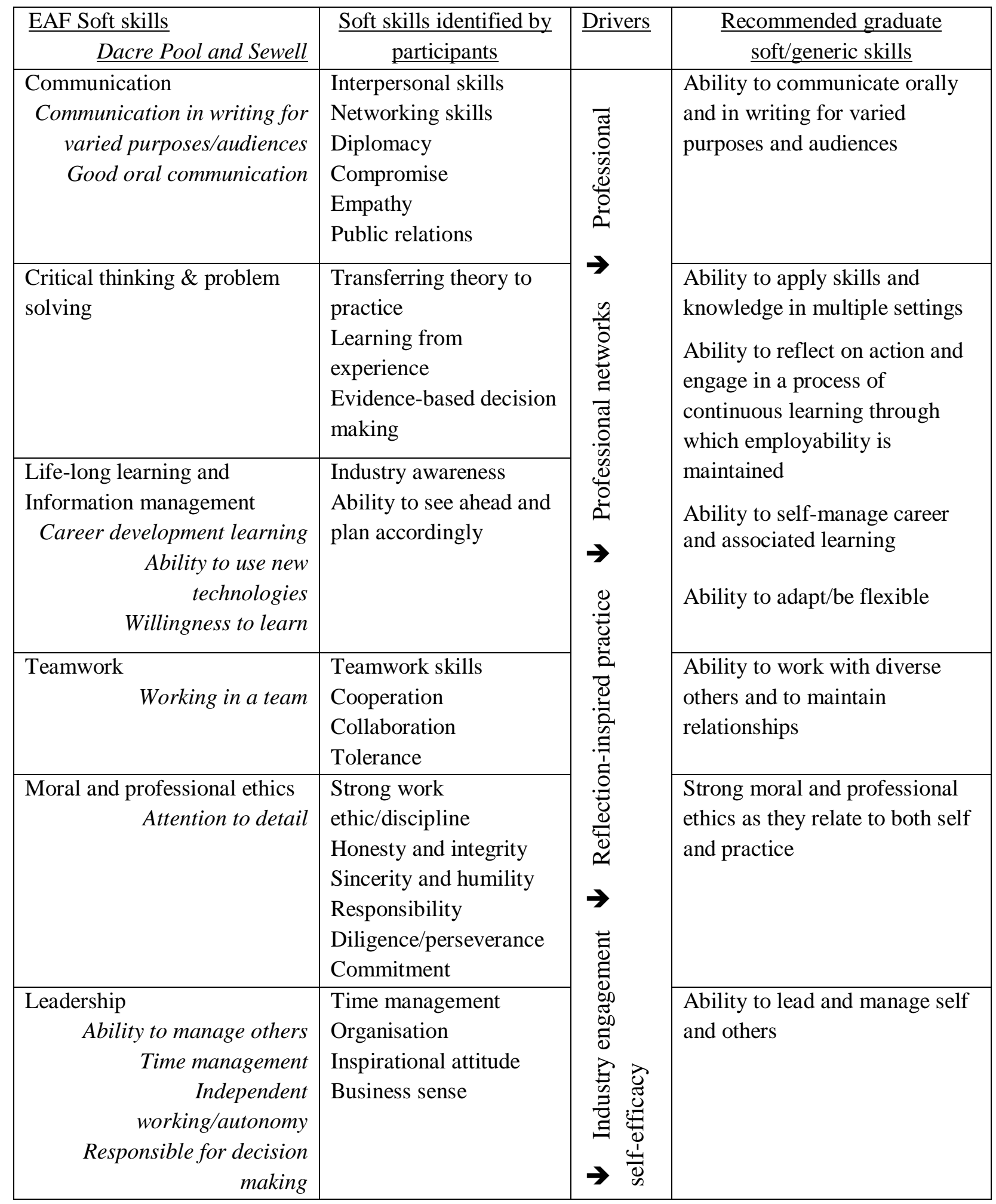




\begin{tabular}{|c|l|l|l|}
\hline Plan, coordinate and organise & & \\
\cline { 1 - 2 } $\begin{aligned} \text { Entrepreneurship } \\
\text { Enterprising }\end{aligned}$ & $\begin{array}{l}\text { Adaptability/flexibility } \\
\text { Confidence and courage } \\
\text { Imagination/creativity }\end{array}$ & & $\begin{array}{l}\text { Capacity and willingness to } \\
\text { develop, communicate and } \\
\text { progress ideas and innovations }\end{array}$ \\
\hline
\end{tabular}

We end with the limitations of the study and suggestions for future research. The Malaysian emphasis on soft skills development within schools indicates that the importance of such skills has been acknowledged. Similarly, the development of the My3S instrument to measure university graduates' soft skills attainment illustrates a commitment to these skills at the level of higher education. However, data from these surveys, which would give institutions valuable information regarding the success of programs in terms of academic preparation and personal attributes, are not released. As such, empirical research remains the most effective mode of music education research.

The Malaysian music industry is relatively small, and practitioners tend to be well networked. For this study, the close-knit network enabled eight established and experienced practitioners to offer a representative view of the nature of music careers in Malaysia. This is, however, a small sample, and we do not seek to generalise. Future research might seek a broader sample, comparison with multiple locations and systems, and feedback from current students and educational developers. Such research might include longitudinal mapping of student progress using validated instruments. We also note that the theoretical component of the study was a difficult task because little information is available in the public domain. Information on the Malaysian context will need to be updated as the rapid change continues.

\section{Concluding comments}

In this article we first presented a review of the significant change across Malaysian education and the unprecedented focus on the need for soft or generic skills within both school-level and higher education. We then discussed the views of eight established music professionals. The 
professionals agreed that while high-level musical skills are essential, soft skills are equally important to graduates' ability to sustain their careers in music. Moreover, for soft and hard skills to heighten employability they need to have already been applied within an industry based, reflection-inspired practice. These are the "drivers" without which any employability initiative will fail to make meaningful change.

The Malaysian government has implemented new ideas and measures in tertiary education with the hope of ensuring a more prepared and holistic graduate with better chances of employability. This has evolved from an initial seven soft skills in the My3S through to the translation of these into the Ministry's nine domains of learning and, currently, to the concept of an Integrated Cumulative Grade Point Average aligned with the eight new domains of the Malaysian Qualifications Framework.

To produce graduates with all the desired attributes, higher music educators need a more holistic and dynamic approach to the delivery of knowledge that will inspire all students to go beyond what is in the classroom and explore their full potential. This is an international concern given the increasing demand for employable graduates and decreasing funding for higher education learning and teaching. Implications include the need to afford higher music educators the time, resources and expertise that will enable them to activate the drivers of employability with all students. This is likely to require change in the ways in which quality teaching is assessed, and a review of how it is valued in rewards and recognition processes and also in terms of career advancement.

In employability terms, the narratives of the Malaysian music professionals who participated in this study related to the accrual of social, reputational and cultural capital. These career capitals form a vital element of employability (Tomlinson, 2007) for musicians, particularly in industries such as music where networked forms of employment dominate Bennett \& Burnard, 2016). Most music degree programs address both professional (hard) and soft (generic) skills. 
Many programs also incorporate opportunities for students to work in industry. However, and in line with the need for support and professional development among higher music educators outlined above, few programs explicitly address employability, teach students to reflect, or introduce an employability framework that enables students to become familiar with the need for, and their development in relation to, hard and soft skills - to build their career capital. The explicit focus on the cognitive dimensions of employability through experiential learning emerges as a worthy challenge.

\section{References}

Abas, A. \& Koi, K. L. (2014). DPM: Education plan working. New Straits Times, June 18, p. 4. Bandura, A. (1986). Social foundations of thought and action: A social cognitive theory. Englewood Cliffs, NJ: Prentice Hall.

Barkl, L. (2008). Professional musicians and the music education programs of arts organisations. In D. Bennett \& M. Hannan (eds.), Inside, outside, downside up: Conservatoire training and musician's work (pp. 61-72). Perth: Black Swan Press.

Bartleet, B., Bennett, D., Bridgstock, R., Draper, P., Harrison, S., \& Schippers, H. (2012). Preparing for portfolio careers in Australian music: Setting a research agenda. Australian Journal of Music Education, 2012(1), 32-42.

Bennett, D. (2016). Developing employability in higher education music. Arts and Humanities in Higher Education, 15(3-4), 386-395. doi: 10.1177/1474022216647388

Bennett, D., Richardson, S., \& MacKinnon, P. (2016). Enacting strategies for graduate employability: How universities can best support students to develop generic skills. Sydney: Australian Government Office for Learning and Teaching.

Bennett, D., \& Burnard, P. (2016). Human capital career creativities for creative industries work: Lessons underpinned by Bourdieu's tools for thinking. In Comunian, R., \& Gilmore, 
A. (Eds). Higher education and the creative economy: Beyond the campus (pp. 123-142). London: Routledge.

Dacre Pool, L. \& Sewell, P. (2007). The key to employability: Developing a practical model of graduate employability. Education + Training, 49(4), 277-289.

Frenette, A., \& Tepper, S. J. (2016). What difference does it make? Assessing the effects of arts-based training on career pathways. In Comunian, R., \& Gilmore, A. (Eds). Higher education and the creative economy: Beyond the campus (pp. 83-101). London: Routledge.

Ghazali, G. M. (2006). Factors influencing Malaysian children's motivation to learn music.

Doctoral dissertation University of New South Wales, Australia.

Hillage, J., \& Pollard, E. (1998). Employability: Developing a framework for policy analysis. London: Department for Education and Employment.

Kolb, D. A. (1984). Experiential learning: Experience as the source of learning and development. New Jersey: Prentice-Hall.

Ministry of Education, Malaysia. (2013). Malaysia Education Blueprint 2013-2025 (Preschool to post-secondary education). Putrajaya: Ministry of Education.

Ministry of Higher Education Malaysia. (2010). Future direction of music education in Malaysian public higher education institutions. Putrajaya: Ministry of Higher Education.

Ministry of Higher Education Malaysia. (2010). Malaysian Soft Skills Scale (My3S). http://jpt.mohe.gov.my/my3s/members/index_home.php

Ministry of Higher Education Malaysia. (2012). The National Graduate Employability Blueprint 2012 - 2017. Putrajaya: Ministry of Higher Education Malaysia.

Mohamad, Z. (2014). Soft skills development. In Life \& Times, New Sunday Times, Jan 26, p. 3. Pike, P. (2014). Newly minted professional pianists: Realities of teaching, performing, running a business and using technology. In Carruthers, G. (Ed.). Relevance and reform in the 
education of professional musicians. 20th ISME Commission for the Education of the Professional Musician (pp. 86-92). Perth: ISME.

Pillai, S., Khan, M. H., Ibrahim, I. S. \& Raphael, S. (2012). Enhancing employability through industrial training in the Malaysian context. Higher Education, 63(2), 187-204.

Smilde, R. (2009). Musicians as lifelong learners: Discovery through biography. Delft: Eburon Academic Publishers.

Syed Aris, S. R. (2012). Level of soft skills amongst UiTM undergraduate students. My3S http://prezi.com/q7somj8ndqfb/level-of-soft-skills_my3s/

Tolmie, D. (2014). Identifying, analysing and aligning "the dream" with vocational preparation: An investigation into first-year music undergraduate career aspirations and motivations. In Carruthers, G. (Ed.). Relevance and reform in the education of professional musicians. 20th ISME Commission for the Education of the Professional Musician (pp. 8692). Perth: ISME.

Tomlinson, M. (2007). Graduate employability and student attitudes and orientations to the labour market. Journal of Education and Work, 20(4), 285-304.

Yorke, M. (2004). Employability in higher education: What it is, what it is not. York: The Higher Education Academy. 